\title{
The Effect of Bank Behavior, Financial Literacy on Financial Inclusion and Debt Behavior in Household Consumption
}

\author{
Herispon ${ }^{1}$, Tafdil Husni ${ }^{2}$, Elfindri ${ }^{2}$, and Harif Amali Rivai ${ }^{2}$ \\ herisponpiliang@gmail.com \\ Academy of Finance and Banking Riau (AKBAR), Pekanbaru, Indonesia ${ }^{1}$, Faculty of Economics, Universitas Andalas, Padang, \\ Indonesia ${ }^{2}$
}

\begin{abstract}
This research analyzes the influence of Bank Behavior, Financial Literacy on Financial Inclusion, Debt Behavior in Household Consumption. Using a purposive sampling method with 303 households. Data analysis and hypothesis test used in this research are SEM-WarpPLS, hence from this study, we found that banking behavior has significant influence to financial inclusion, a significant influence on debt behavior, and has a significant effect on household consumption. Also found simultaneous influence is R2 of 0.18 in financial inclusion, meaning financial inclusion can be explained by the banking behavior and financial literacy of $18 \%$. R 2 of 0.43 in debt behavior, meaning that debt behavior can be explained by banking behavior, financial literacy and financial inclusion by $43 \%$. $\mathrm{R} 2$ is 0.14 in household consumption, meaning that household consumption can be explained by banking behavior, financial literacy, financial inclusion and debt behavior of $14 \%$.
\end{abstract}

Keywords: Banking Behavior, Know Your Customer, Debt Behavior.

\section{Introduction}

Bank's behavior; Household expectations for wider access to credit from formal financial institutions as a form of financial inclusion are still obstacles, these barriers are derived from binding rules from central banks or laws relating to national banking and formal financial institution policy itself : 1) Know Your Customer is an action taken to recognize the customer. 2) Prudential Banking, is a prudent principle that a formal financial institution conducts to its customers. 3) Risk Aversion, because the bank's business is a conservative business. The tendency to the conservative nature, the bank is careful in running its business. So that risk aversion is compensated as part of the risks such as interest expenses incurred by relatively high households coupled with the provision of adequate collateral and easily disbursed. Such problems indicate that access to banking services, especially credit, is still felt difficult by households, especially small and medium enterprises [1].

Jacobsen [2] states particularly the lending of consumer loans to households in relation to the expectations and policies of the formal financial institutions themselves: the bank's profitability expectations to customers, the capacity of customers, the expectation of repayment, and the value of collateral required from customers, household income and income from interest expense. If these expectations and policies are positively correlated with the prediction of formal financial institutions, then the loans disbursed to household sectors are assumed to be loose. Conversely, if these expectations and policies are negatively correlated with predictions of formal financial institutions, the loans disbursed to household sectors may become narrow, this principle is a reference in the operation of formal financial institutions [2]

Financial Literacy; In the household life many aspects are learned to achieve family welfare, among them is the aspect of financial management, where financial management related to income and expenditure within a certain period. Revenue can come from the income of the head of household or family member, in the form of salary and wages received routine every month plus income received not routine, while for expenditure allocated for all purposes and household needs within a certain period. So that in the household financial management required knowledge, abilities, and financial management skills. Financial Literacy deals with financial management on mortgages, leases, bank deposits, the establishment of pension funds, investments, debt and others [3]-[5].

Furthermore, Definite, SEADI, OJK [6], Bank Indonesia and LDUI [7], Huston [8] that financial literacy can be influenced by family background, friendship and education environments that can be obtained through formal education such as higher education and through informal education in the family environment shown by the knowledge, attitude and behavior of the head of the family or family members in financial management. According to Mian and Sufi [9] knowledge and financial management correlate with the increase or decrease in debt behavior and repayment behavior. Meanwhile, according to Kamil, et al. [10] and Brown, et al. [11] the ultimate goal of financial literacy in households is to avoid bankruptcy due to debt and can reduce interest for debt. 
Financial inclusion; Already a global issue among developing and developed countries and still a topic of discussion in various international forums, the financial inclusion is a correction to financial exclusive that is a financial condition that only benefits a few people.

Hannig and Stefan [12] argue that financial inclusion is aimed at reaching all levels of society in banking services. Then Cámara and Tuesta [13] stated that financial inclusion to maximize the use, access, and minimize financial exclusive and postulate that the level of financial inclusion is determined by three dimensions namely; user, barrier, access. This dimension at the same time is determined by the indicator of the demand side and the indicator from the supply side.

Furthermore, the World Bank revealed there are four types of financial services that are considered crucial to the life of the community, namely; fund storage services, credit services, payment system services, and insurance including pension funds [14]. The World Bank also states that the financial inclusion indicator that can be used as a measure of the development of financial inclusion is; a) access that measures the ability of the use of formal financial services in terms of physical affordability and price, b) the user is to measure the actual capability of the use of financial products and services such as regularity, frequency, duration of use, c) quality is to measure whether the attributes of financial products and services have to meet customer needs, d) wealth that measures the impact of financial services on the life of the users of financial services [14].

Bank Indonesia [1] explains that financial inclusion must be viewed from two sides, namely the supply and demand side. The supply side; efforts to embrace all walks of life to utilize deposit products, access, use, services, and other banking services. Demand-side; efforts to embrace the layers of society to take advantage of access, use, credit services channeled by formal financial institutions. Particularly in access to credit of formal financial institutions there are two parts namely; 1) credit financing for investment or productive sectors to micro, small, medium and large enterprises aimed at increasing the value of goods, 2) credit financing for the consumer sector which aims to improve the quality of life and stability of household consumption.

In practice, financial inclusion has not proceeded like a household expectation because in the study Wibowo (2007) cited from Maryatmo and Rahayu [15] found some obstacles to access to loan services include; complicated procedures and requirements, high-interest rates, the frequency of payments, the terms of payment, the collateral, the amount of the loan not in accordance with the demand. Budianto's [16] study also supports that the services and access to credit perceived by the community are still difficult regarding banking administration rules. Then the survey results BPS and the Ministry of Cooperatives SME [17] that access to credit services is still difficult among others; loan application procedures, no interest, no collateral, no procedures, high-interest rates, and rejected proposals.

While the purpose of financial inclusion is for formal or non-formal financial institutions to provide convenience in services and expansions to be enjoyed by households, such as ease of procedure, requirements, competitive interest rates [18], rapid loan disbursement process, providing credit card-borne facilities, expanding the marketing network by opening branch offices in certain areas, extending the reach of community services with ATM networks, internet banking applications, and so on [19].

The actions taken by these formal financial institutions face two consequences: 1) activities of embracing all walks of life in access to savings and loans as a form of financial inclusion program, 2) to run the bank's own internal policy of identifying customers with prudential principles to avoid or minimize risks arising from the effect of financial inclusion carried out. It is clear that formal financial institutions operate two policies at once in which they can complement or contradict each other, so whether the financial inclusion is maximized while on the other hand, the formal financial institution holds the principle of prudence in the sense that the bank always minimizes the risks and not wanting a net performance loan derived from household consumption loans contributed significantly.

Household Debt Behavior; The impetus of higher standards of living, social recognition, and imitation of upperclass life by the lower classes, people whose real incomes are fixed, those with real fixed income contribute to household debt [20]. Furthermore, the pattern of social relations can be the cause of the discontent and disappointment experienced by households in their standard of living [21], where households mimic the behavior they observe around them and their social reference groups [22], so they get into debt. Then Innes [23] put forward three elements in his debt theory namely; 1) a loan occurs because of an agreement between the party giving with the receiving party, 2) the formal financial institution can be an efficient machine in the provision of credit or loans, 3) a good debtor is to pay any form of debt. So whatever the reasons are arising from the cause of debt, used for any debt, the point of the knot is the debt is always reduced, and any debt must be repaid.

Furthermore, consumer loans from banks, nonbanks play a dominant role in encouraging different consumption between households with varying levels of debt. The efforts made by the banking and nonbanking parties are in order to increase the expansion of its products, services and loan volume [14], [24],[25] with maximum profit objectives. Supported by the use of technology and information by banks and non banks in introducing their products through the media visual media, print media, radio media, internet media and others, with the aim to stimulate the desire and intention of household behavior into real behavior to have a product through the road debt [26]. Although there are indications that consumer lending is attractive and lucrative, increasing consumer lending with various variations of credit, especially credit cards, food, and non-food credits with easy requirements, especially offered by formal financial institutions, or suppliers of goods and services [27]. 
So in the life of a household, it is found that debt can contribute positively or negatively. The positive contribution of debt in domestic life refers to studies conducted by [28] found that debt contributes to encouraging household life toward the desired progress and well-being. Studies from Johnson and Li [18] found that debt can maintain and improve lifestyles. In the Muzeto study [29] that debt in the short run can increase household consumption and contribute to economic growth. Ultimately debt is an important and useful part of modern life when debt can be well managed [30]. From the results of this study it can be concluded that household debt behavior can bring households to a better standard of living when debt can be controlled, and households assume that debt is a liability that must be repaid and does not consider debt as a heavy burden borne, if the debt is considered as a load then somewhere when this load can be released or avoided the load.

While the negative contribution of debt in household life is more felt in the long-term period: increasing consumer spending [29] increasing household vulnerability with debt repayment conflict [31] lowering household consumption [32] lowered aggregate saving rates, many of which are deemed to be negatively related to long-term consumption growth [33], [34]. Then the behavior of household debt can lead to various impacts for the household itself, that is, the economic impact is correlated with poverty or welfare, the social impact of social status is increased or excluded from society, as well as the psychological impact of having a high lifestyle or chronic stress [35].

From the exposure of concepts and theories that have been described the researchers try to build the research hypothesis as follows:

1. Banking behavior positively affects financial inclusion

2. Banking behavior has a positive effect on debt behavior

3. Banking behavior has a positive effect on household consumption

4. Financial literacy has a positive effect on financial inclusion

5. Financial literacy has a positive effect on debt behavior

6. Financial literacy has a positive effect on household consumption

7. Financial inclusion has a positive effect on debt behavior

8. Financial inclusion has a positive effect on household consumption

9. Debt behavior has a positive effect on household consumption

Through this research, the researcher tried to show the influence of bank behavior, financial literacy toward financial inclusion and household debt behavior, followed by process in this study through several stages namely; 1) introduction, 2) research methods, 3) results and discussion, 4) conclusions, limitations, future research suggestions.

\section{Research Methods}

The design of this research is survey research with purposive sampling method by using a sample of 303 respondents of the household unit in Pekanbaru City, Riau Indonesia. The sampling period is conducted from December 2017 to January 2018. Indicators of financial literacy refer to the study Kempson el at (2005) cited from Definite, SEADI and OJK [36], Xiao and Wu [37] covering four dimensions: managing finances, forward financial planning, making choices in financial arrangements, and look for financial information developed in 9 indicators. The financial inclusion indicator used in this study refers to the limits issued by the World Bank, namely: Access, User, Quality, and Wealth [7] developed in 18 indicators. For bank behavior, the dimensions used are Know Your Customer Principles referring to Bank Indonesia Regulation (PBI) no. 3/10/PBI/2001 concerning Application of Know Your Customer Principles, Prudential Banking and Risk Aversion Principle referred to Act number 23 of 1999 concerning Bank Indonesia Article 25 and developed in 9 indicators. Household debt behavior indicators include three dimensions developed in 9 indicators based on the results of studies related to household debt. Indicators in household consumption include three dimensions developed in 6 indicators based on the results of studies related to household debt. The indicator is measured by Liker scale in gradations 1 through 5, i.e. strongly disagree value 1 , disagree value 2 , simply agree value 3 , agree value 4 , strongly agree value 5 . In the use of this gradation do not use neutral because in the life of the household only two choices of debt and no debt. Subsequent modeling, analysis, and hypothesis testing is done by using SEM-WarpPLS program.

\section{$3 \quad$ Results and Discussion}

After the research data inputted in the program SEM-warpPLS with 5 latent constructs then obtained the research model as follows: 


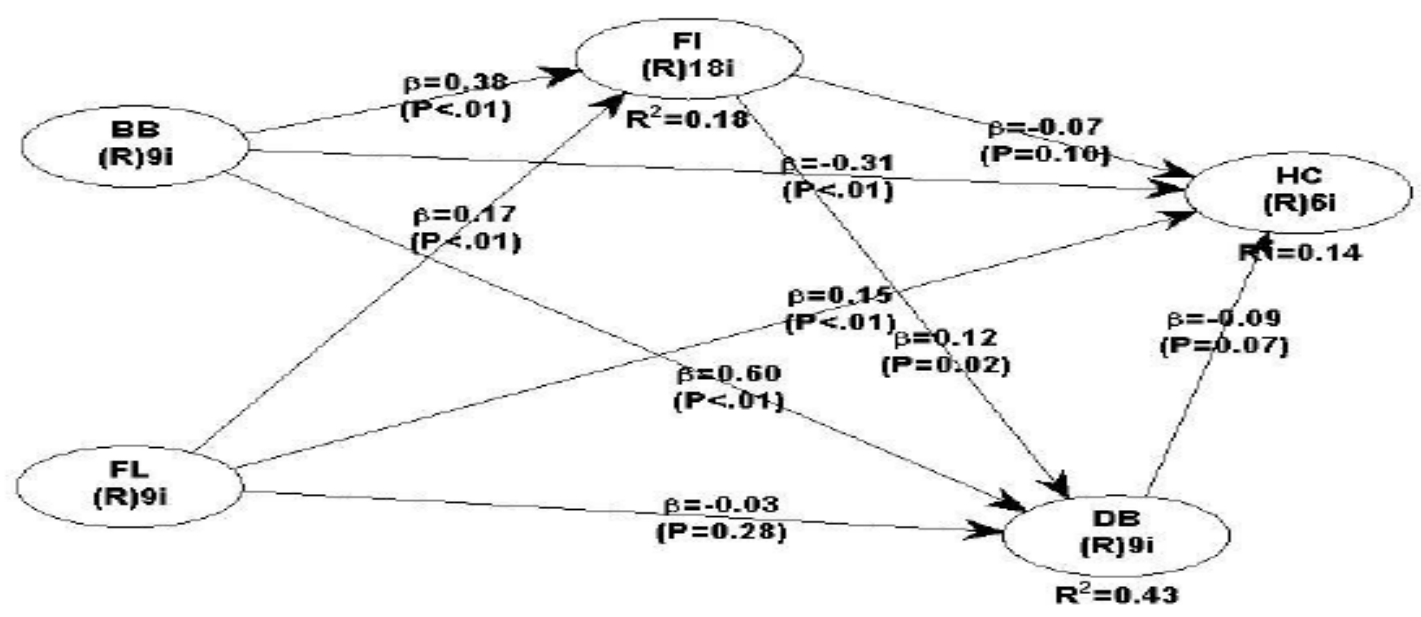

Fig. 1. Results SEM-warpPLS

Source: results of research data 2018

Note : Banking Behavior $=$ BB, Financial Literacy $=$ FL, Financial Inclusion $=$ FI, Debt Behavior $=$ DB, Household Consumption $=$ HC

The size and model used to evaluate the relationship between the constructs is to use the general result output including: a) the criterion of good of fit average parth coefficient model of 0.213 significant value of $\mathrm{P}<0.001$, b) average R-squared of 0.250 level significant value $\mathrm{P}<0.001$, c) average variance inflation factor of 1.201 with the limit must be small from 5, meaning that the general terms in the model have been met. Furthermore, the assessment of reliability and validity of the indicator of the instrument, in the SEM warpPLS known as the outer model, the requirement that must be met on the convergent validity with loading $\geq 0.70$ at the value of $\mathrm{P}<0.05$ and the discriminant validity value should be lower than the construct [34]. Since the instruments in this model are self-evident, we use a reference factor of loading factor between 0.40 to 0.70 to be considered for this study [39]. While the limits for composite reliability and Cronbach's alpha with restrictions $\geq 0.70$, for this study, can be seen in the following table:

Table 1. Loading factor dan Composite Reliability.

\begin{tabular}{lllllc}
\hline Item & $\begin{array}{l}\text { Banking } \\
\text { Behavior }\end{array}$ & $\begin{array}{l}\text { Financial } \\
\text { Literacy }\end{array}$ & $\begin{array}{l}\text { Financial } \\
\text { Inclusion }\end{array}$ & \multirow{2}{*}{ Debt Behavior } & $\begin{array}{c}\text { Household } \\
\text { Consumption }\end{array}$ \\
\hline Loading*** & 0.651 & 0.588 & 0.531 & 0.631 & 0.849 \\
Composite Reliability & 0.871 & 0.827 & 0.811 & 0.857 & 0.939 \\
Cronbach's Alpha & 0.832 & 0.764 & 0.798 & 0.812 & 0.923 \\
Full Collinearity VIF & 1.836 & 1.221 & 1.075 & 1.749 & 1.073 \\
R-squared & & & 0.179 & 0.433 & 0.137 \\
Q-squared & & & 0.184 & 0.442 & 0.112 \\
\hline
\end{tabular}

*** significan $p$-value $<0.001$ 
From table 1 the results obtained for each construct shown such as Banking Behavior, Financial Literacy, Financial Inclusion, Debt Behavior, Household Consumption show the loading factor of each indicator above 0.40 at the significant level of $p$-value $<0.001$ means the contribution of validity to its latent construction is acceptable. Then the result on composite reliability with the limit of 0.80 as a requirement for composite reliability has been fulfilled, as well as for Cronbach's alpha with values above 0.70 means the requirement for Cronbach's alpha has been fulfilled while the limit is $\geq 0.70$. For full Collin VIFs that indicate no multicollinearity, either lateral or lateral, the criteria for full collinearity test is the value should be lower than 3.3 [38] results show that the acquisition of full collin test for all constructs under 3.3 this means the model is free from the problems collinearity of vertical, lateral, and common method bias. For Q-squared in endogenous latent variables meaning greater than zero and positive, the model estimate shows good predictive validity that is greater than 0 .

Data analysis and hypothesis testing of Behavior Banking, Financial Literacy, Financial Inclusion, Debt Behavior, Household Consumption are based on the results in the following table:

Table 2. Analysis 9 Hypotheses On Total Effect.

\begin{tabular}{|c|c|c|c|c|c|c|c|c|c|c|c|}
\hline \multirow[b]{2}{*}{ Path } & \multicolumn{3}{|c|}{ Direct Effect } & \multicolumn{3}{|c|}{ Indirect Effect } & \multicolumn{3}{|c|}{ Total Effect } & \multirow[b]{2}{*}{ Hipotesis } & \multirow[b]{2}{*}{$\begin{array}{c}\text { Explanati } \\
\text { on }\end{array}$} \\
\hline & $\begin{array}{c}\text { Coefficie } \\
\text { nts }\end{array}$ & $\begin{array}{c}\text { p- } \\
\text { value }\end{array}$ & $\begin{array}{c}\text { Effect } \\
\text { size }\end{array}$ & $\begin{array}{c}\text { Coefficie } \\
\text { nts }\end{array}$ & $\begin{array}{c}\text { p- } \\
\text { value }\end{array}$ & $\begin{array}{c}\text { Effect } \\
\text { size }\end{array}$ & Coefficients & $\begin{array}{c}\text { p- } \\
\text { value }\end{array}$ & $\begin{array}{c}\text { Effect } \\
\text { size }\end{array}$ & & \\
\hline BB --> FI & 0.380 & $<0.001$ & 0.147 & & & & 0.380 & $0.001 * * *$ & 0.147 & H1 & accepted \\
\hline BB --> DB+) & 0.599 & $<0.001$ & 0.388 & 0.046 & 0.129 & 0.030 & 0.645 & $0.001 * * *$ & 0.418 & $\mathrm{H} 2$ & accepted \\
\hline BB $-->\mathrm{HC}+)$ & -0.306 & $<0.001$ & 0.090 & -0.083 & 0.072 & 0.024 & -0.389 & $0.001 * * *$ & 0.114 & H3 & accepted \\
\hline FL --> FI & 0.170 & $<0.001$ & 0.032 & & & & 0.170 & $0.001 * * *$ & 0.032 & $\mathrm{H} 4$ & accepted \\
\hline FL -> DB-) & -0.034 & 0.278 & 0.002 & 0.021 & 0.306 & 0.001 & -0.013 & 0.410 & 0.001 & H5 & rejected \\
\hline FL --> HC-) & 0.149 & 0.004 & 0.024 & -0.011 & 0.421 & 0.002 & 0.138 & $0.007 * * *$ & 0.026 & H6 & accepted \\
\hline FI $-->$ DB & 0.121 & 0.017 & 0.043 & & & & 0.121 & $0.017 * *$ & 0.043 & $\mathrm{H} 7$ & accepted \\
\hline FI --> HC+) & -0.074 & 0.097 & 0.010 & -0.010 & 0.400 & 0.001 & -0.084 & $0.069 *$ & 0.011 & H8 & accepted \\
\hline DB $-->\mathrm{HC}$ & -0.085 & 0.067 & 0.013 & & & & -0.085 & $0.067 *$ & 0.013 & H9 & accepted \\
\hline
\end{tabular}

From the table above can be explained that there are three indirect paths that strengthen the direct influence on the total influence that is $\mathrm{BB}-->\mathrm{DB}^{+}, \mathrm{BB}-->\mathrm{HC}^{+)}, \mathrm{FI}-->\mathrm{HC}^{+)}$and there are two indirect pathways that weaken the direct influence on the total influence of ie FL --> $\mathrm{DB}^{-)}$and $\mathrm{FL} \mathrm{-->} \mathrm{HC}^{-)}$so that this influence reinforces or weakens the direct influence on the total influence to determine the decision in the hypothesis test. Furthermore, each acquisition value and number are described as follows : The value of 0.380 on the BB line $\rightarrow$ FI if BB increases 1 variance then the FI increases by 0.380 variance and the hypothesis test results show that the banking behavior has a positive effect on financial inclusion and significant on $\mathrm{p}$-values 0.001 means $\boldsymbol{H}_{\boldsymbol{1}}$ accepted. The value of 0.645 on the BB line $->$ DB when BB increases 1 variance than the DB increases by 0.645 variance and the hypothesis test results show that the banking behavior has a positive effect on debt behavior and significant on p-values 0.001 means $\boldsymbol{H}_{2}$ accepted. The value of -0.389 on the BB line $->\mathrm{HC}$ when BB increases 1 variance then $\mathrm{HC}$ decreases by 0389 variance and hypothesis test results show that banking behavior has negative effect on household consumption and significant on p-values 0.001 means $\boldsymbol{H}_{3}$ accepted.

The value of 0.170 on the FL -> FI path when FL increases 1 variance than the FI increases by 0.170 variance and the hypothesis test results show that financial literacy has a positive effect on financial inclusion and significant on p-values 0.001 means $\boldsymbol{H}_{4}$ is accepted. The value of 0.013 in FL $\rightarrow$ DB path when FL increases 1 variance then DB decreases by -0.013 variance and hypothesis test results show that financial literacy negatively affects debt behavior and 
significant at p-values 0.410 means $\boldsymbol{H}_{5}$ is rejected. The value of 0.138 on the path of FL -> HC when FL increases 1 variance then $\mathrm{HC}$ increases by 0138 variance and hypothesis test results show that financial literacy has a positive effect on household consumption and significant on p-values 0.007 means $\boldsymbol{H}_{6}$ accepted. The value of 0.121 on the FI $\rightarrow>$ DB path when FI increases 1 variance then the DB increases by 0.121 variance and the hypothesis test results show that financial inclusion has a positive effect on debt behavior and significant on p-values 0.017 means $\boldsymbol{H}_{7}$ accepted. The value of -0.084 on the FI -> HC line when FI increases 1 variance then the $\mathrm{HC}$ decreases by -0.084 variance and the hypothesis test results show that financial inclusion negatively affects the household consumption and significant at p-values 0.069 means $\boldsymbol{H}_{8}$ accepted. The value of -0.085 on the DB $\rightarrow$ HC path when DB increases 1 variance then HC decreases by -0.085 variance and hypothesis test results show that debt behavior has negative effect on household consumption and significant at p-values 0.067 means $\boldsymbol{H} \boldsymbol{g}$ accepted.

While in simultaneous effect shown by R-squared equal to 0.18 which means financial inclusion variance can be explained together by banking behavior and financial literacy equal to $18 \%$, then R-squared equal to 0.433 which means a variance of debt behavior together can be explained by banking behavior, financial literacy, and financial inclusion by $43.3 \%$. Furthermore, R-squared of 0.137 , which means the variance of household consumption can be explained together can be explained by banking behavior, financial literacy, financial inclusion, and debt behavior by $14 \%$.

\section{Conclusions}

This research analyzes the influence of banking behavior, financial literacy toward financial inclusion, debt behavior in household consumption. This research finds that: 1) banking behavior has a significant effect on financial inclusion, meaning that the loosening of banking behavior is wider the reach of financial inclusion in the community, 2) the banking behavior has a significant effect on household debt behavior, meaning the loosening of banking behavior the bigger the chance of the household for debt, 3) banking behavior has a significant negative effect on household consumption, which means that the more loosely the banking behavior the more acces and the user used by the household, the greater the burden borne by the household, 4) financial literacy has a significant effect on financial inclusion, the financial literacy of households is increasingly acces, users, financial services and banking enjoyed by households, 5) financial literacy in this study can not predict debt behavior, but still fulfill the theoretical assumption that is a negative sign on the coefficient path, meaning that the higher the financial literacy household, the less interest in debt, 6) financial literacy has a significant influence on household consump-tion, meaning that the higher the financial literacy the greater the opportunity to increase household consumption, 7) financial inclusion has significant effect on debt behavior, meaning that the higher the inclusion level the more significant the access to debt, 8) the financial inclusion has a significant negative effect on household consumption, which means increased inclusion of increase in debt, the burden in household is increasing, 9) debt behavior has a significant negative effect on household consumption, it means that the increase in debt is the increase of household expenses and debt must be repaid and the debt repayment reduces the level of household consumption, the results of this study are in line with the study of Baker [32], Ekici and Dunn [33], and Bunn [34].

The barriers of financial inclusion are predicted to be derived from the bank's behavior, namely: a) expectations and predictions of formal financial institutions to households about the 
laxity of expected expansion of credit and profit, b) internal policies adopted by formal financial institutions such as KYC principles, prudential banking, and risk aversion can actually be a barrier to financial inclusion, c) the high or low capacity and awareness of debt-paying behavior of households, d) suspicion within certain limits and administrative requirements remains a constraint that will undermine household interest in relating to financial institutions. This research is only conducted from the demand side, for future research can be done on the supply side with SEM-AMOS or LISREL and other analysis tools.

Acknowledgments. To the Prof. Dr. Tafdil Husni, SE. MBA., Prof. Dr. Elfindri, SE. MA., Dr. Harif Amali Rivai, SE. M.Si who has guided the writer's dissertation and provided direction in the writing of this article.

\section{References}

[1] Bank Indonesia. 2015. dalam http://www.neraca.co.id/article/24079/bi-inklusi-keuangan-harusseimbang-antara-penawaran-dan-permintaan, accessed December 21, 2015.

[2] Jacobsen, Dag Henning. 2004. What Influences The Growth Of Household Debt ? Economist in the Securities Markets Department, and Bjørn E. Naug, senior economist in the Research Department, Norges Bank, Economic Bulletin 2004 - Q 3, pp ; 1-9

[3] Imawati, Indah., Susilaningsih., Ivada, Elvia (2013) Pengaruh Financial Literacy Terhadap Perilaku Konsumtif Remaja Pada Program IPS SMAN Surakarta TA 2012/2013. PE-BKK Akuntansi FKIP. Universitas Sebelas Maret. Jupe UNS Volume 2 Nomor 1 48-58.

[4] Luzardi, Annamaria., Mitchell, Olivia S (2014) The Economic Importance of Financial Literacy : Theory and Evidence. Journal of Economic Literature, Vol. LII (March 2014- 52(1), pp ; 544.

[5] Glaser, Markus., Walther, Torsten (2013) Run, Walk, or Buy? Financial Literacy, Dual-Process Theory, and Investment Behavior. Universität München, Munich School of Management, Schackstraße 4, 80539 München, Germany. JEL-Classification Code: G11, D81. pp ; 1-35.

[6] Definit, SEADI, dan OJK (2013) Developing Indonesian Financial Literacy Index. Financial Report, DEFINIT is a research, consulting, and training institute with expertise in development and finance, economic policy, financial inclusion, microfinance, early warning system, crisis surveillance, policy intelligence with smart technology, business intelligence, banking, and governance. SEADI (The Support for Economic Analysis Development in Indonesia). OJK (Otoritas Jasa Keuangan, Indonesia Financial Services Authority).

[7] Bank Indonesia dan Lembaga Demografi Universitas Indonesia (2014) Financial Literacy Baseline Survey (FLBS). http://www.bi.go.id/ accessed, December 8, 2015.

[8] Huston, S.J (2010). Measuring financial literacy. Journal of Consumer Affairs Volume 44 Issue 2 .

[9] Mian, Atif and Sufi, Amir (2011) Consumers and the Economy, Part II : Household Debt and the Weak U.S. Recovery. Federal Reserve Bank of San Francisco (FRBSF) Economic Letter, 2011-02 January 18, 2011, pp ; 1-5.

[10] Kamil, Nik Sari Syerina, Nik., Musa, Rosidah., Sahak, Siti Zaleha (2014) Examining the Role of Financial Intelligence Quotient (FiQ) in Explaining Credit Card Usage Behavior: A Conceptual Framework. Procedia-Social and Behavioral Sciences 130 ( 2014 ) pp ; 568 - 576.

[11] Brown, Sarah., Karl Taylor, Stephen Wheatley Price (2005). Debt and distress: Evaluating the psychological cost of credit. Journal of Economic Psychology 26 (2005) pp ; 642-663.

[12] Hannig, Alfred and Stefan, Jansen (2010) Financial Inclusion and Financial Stability: Current Policy Issues. ADBI Working Paper 259. Tokyo: Asian Development Bank Institute. Available: http://www.adbi.org/working-paper/2010/12/21/4272.financial.inclusion.stabi lity. policy.issues/ 
[13] Cámara, Noelia., Tuesta, David (2014) Measuring Financial Inclusion : A Multidimensional Index. BBVA Research, Working Paper, No. 14/26, Madrid, September 2014, pp ; 1-40.

[14] Bank Indonesia. (2014) Booklet Keuangan Inklusif. Departemen Pengembangan Akses Keuangan dan UMKM Bank Indonesia, pp 1-17.

[15] Maryatmo, R dan Nyoman Yuyun Sri Rahayu (2009) Hambatan Penyerapan Kredit Usaha Kecil Studi Kasus di Pasar Anyar I Singaraja Bali, JEJAK Vol. 2. No. 1, hal 4.

[16] Budianto A. (2013) UMKM Sulit Akses Kredit Perbankan. Dari ; http://ekbis.sindonews.com $/ \mathrm{read} / 2013 / 02 / 11 / 34 / 716626 /$ umkm-sulit-akses-kredit-perbankan, November 2016

[17] BPS dan Kementerian Koperasi (2013) Skema Kredit Usaha Rakyat PT. Bank Rakyat Indonesia dalam http://ekbis. sindonews.com/read/2013/02/11/34/716626/umkm-sulit-akses-kredit-per bankan, di download 13 November 2016.

[18] Johnson, Kathleen W. and Li, Geng (2007) Do High Debt Payments Hinder Household Consumption Smoothing. Finance and Economics Discussion Series Divisions of Research \& Statistics and Monetary Affairs Federal Reserve Board, Washington, D.C, 2007-52, pp ; 1-40.

[19] Brown, Meta., Haughwout, Andrew., Lee, Donghoon., van der Klaauw, Wilbert (2013) The Financial Crisis at the Kitchen Table : Trends in Household Debt and Credit. Federal Reserve Bank of New York. Current Issue in Economics and Finance, Volume 19, Number 2, pp ; 1-19.

[20] Barba, Aldo., and Pivetti, Massimo (2009) Rising household debt: Its causes and macroeconomic implications a long-period analysis. Cambridge Journal of Economics Volume 33, pp ; 113-137

[21] Legge, Jaimie., Heynes, Anne (2009) Beyond Reasonable Debt : A Background Report on the Indebtedness of New Zealand Families. Journals Social Policy Journal Of New Zealand Te Puna Whakaaro Issue 35 June 2009. https://www.msd. govt.nz/about-msd-and-our work/ publications-resour ces/journals-and-magazines/social-policy-journal/spj35/35-beyond reasonable-debt.html, di download, 3 Desember 2015.

[22] Cynamon, Barry Z., Fazzari, Steven M (2008) Household Debt in the Consumer Age: Source of Growth-Risk of Collapse. Capitalism and Society Volume 3, Issue 2, 2008. Article 3, Copyright (C) 2008 The Berkeley Electronic Press. All rights reserved, pp ; 1-32.

[23] Innes, Alfred Mitchell (1913) The Credit Theory of Money. The Banking Law Journal, Vol. 31 (1914), Dec./Jan., Pages 151-168. Edited by L. Randall Wray, Edward Elgar, 2004. Edward Elgar Publishing, Inc. 136 West Street Suite 202 Northampton Massachusetts 01060 USA.

[24] Young Park, Cyn and Mercado, Rogelio (2015) Financial Inclusion, Poverty, And Income Inequality In Developing Asia. Asian Development Bank (ADB) Economics Working Paper series Nomor. 426 January 2015, pp ; 1-25.

[25] Setiawan., Moh. Agung (2015) Analisis Keterkaitan Inklusi Keuangan Terhadap Perilaku Keuangan Personal Masyarakat di Wilayah Kota dan Kabupaten Provinsi Jawa Timur. http://www.jimfeb.ub.ac.id/ index. di download 28 Januari 2016.

[26] Smith, Joanne R., Terry, Deborah J., Manstead, Antony S. R., Louis, Winnifred R., Jacqueline Wolfs, Diana Kotterman., (2008). The Attitude Behavior Relationship in Consumer Conduct: The Role of Norms, Past Behavior, and Self-Identity. Copyright (C) 2008 Heldref Publications. The Journal of Social Psychology, 2008, 148(3), pp ; 311-333.

[27] Herispon (2017) Utang Konsumtif Rumah Tangga Dalam Perspektif Konvensional Dan Syariah. Al-Maqdis: Jurnal Kajian Ekonomi Islam -Volume 2, Nomor 2, Juli-Desember 2017, ISSN 2528-5645. E-ISSN 2528-5661, pp 141-152

[28] Argawal, Ankit. (2013) Early Banking and Money Lending, http://getting moneywise. com/2013 di download 5 September 2015

[29] Mutezo, Ashley (2014) Household debt and consumption spending in South Africa: an ARDLbounds testing approach. Banks and Bank Systems, Volume 9, Issue 4, 2014, pp ; 74-81.

[30] Bank of England. (2010) The Financial Inclusion Centre "Debt And Household Incomes". The Financial Inclusion Centre, Bank of England, NMG, 2010 survey, Reg. No. 6272007, pp ; 1-62.

[31] Reiakvam, Lisa Kristine and Solheim, Haakon (2013) Comparison of household debt relative to income across four Nordic countries. Staff Memos Financial Stability, Macroprudential present reports and documentation written by staff members and affiliates of Norges Bank, the Central Bank of Norway No. 5, pp ; 1-20. 
[32] Baker, Scott R. (2014) Debt and the Consumption Response to Household Income Shocks. Economics Department Stanford University April 2014. Pp ; 1-46

[33] Ekici, Tufan and Dunn, Lucia (2007) Credit Card Debt and Consumption: Evidence from Household-Level Data. Corresponding author: Lucia Dunn, email: dunn.4 @osu.edu; phone: 614-292-8071, pp ; 1-19.

[34] Bunn, Philip (2014) Household Debt And Spending. Quarterly Bulletin 2014 Q3, pp ; 304-315

[35] Williams (2004) dalam http://ruangpsikologi. com/dunia-kerja/awas-terlilit-setan-kre dit/ didown load 22 April 2015.

[36] Definit, SEADI, dan OJK (2013) Developing Indonesian Financial Literacy Index. Financial Report, DEFINIT is a research, consulting, and training institute with expertise in development and finance, economic policy, financial inclusion, microfinance, early warning system, crisis surveillance, policy intelligence with smart technology, business intelligence, banking, and governance. SEADI (The Support for Economic Analysis Development in Indonesia). OJK (Otoritas Jasa Keuangan, Indonesia Financial Services Authority).

[37] Xiao, Jing Jian and Wu, Jiajun (2006) Applying the Theory of Planned Behavior to Retain Credit Counseling Clients. TCAI Working Paper University of Arizona, Take Charge America Institute for Consumer Financial Education and Research, pp ; 1-18

[38] Sholihin, Mahfud dan Ratmono, Dwi (2013) Analisis SEM-PLS Dengan WarpPLS 3.0 Untuk Hubungan Nonlinear dalam Penelitian Sosial dan Bisnis. Edisi ke 1. Andi Offset. Yogyakarta, halaman 1-288.

[39] Hair, Jr, Joseph F., Black, William C., Babin., Barry J., Anderson, Rolph E (2010) Multivariate Data Analysis, Seventh Edition, Copyright (C) 2010. Pearson Prentice Hall. Pp ; 1-761. 